\title{
Biomarkers in Immune Reconstitution Inflammatory Syndrome (IRIS) among People Living with Human Immunodeficiency Virus/Acquired Immunodeficiency Syndrome (HIV/AIDS)
}

Shravan Kumar Mishra', Sundar Khadka ${ }^{1}$, Subhash Dhital ${ }^{1}$, Raj Kumar Mahto ${ }^{1}$ and Krishna Das Manandhar ${ }^{2 *}$

${ }^{1}$ National Public Health Laboratory, HIV Reference Unit, Nepal

${ }^{2}$ Central Department of Biotechnology, Tribhuvan University, Kritipur, Nepal

\begin{abstract}
Background: An Immune Reconstitution Inflammatory Syndrome (IRIS) event is a presentation or a paradoxical worsening of a pre-existing infection following initiation of anti-retroviral therapy in the presence of a decreasing viral load and features consistent with an inflammatory process. This study was conducted to find out the significance of different clinical parameters like hemoglobin, albumin, viral load, erythrocyte, body mass index in the people living with HIVIAIDS with IRIS in Nepalese population.
\end{abstract}

Methods: The study was descriptive with control group. The study included patients who experienced IRIS after initiation of highly active antiretroviral therapy (HAART) with control group as patients who were HIV positive without HAART treatment. This study was carried out on 44 HIV infected individual who initiated HAART and then suffered from IRIS and compared with 56 control HIV infected person without IRIS visiting National Public Health Laboratory (NPHL) for routine HIV viral load testing and CD4 count between April and August, 2014

Results: The patients were categorized into highly active antiretroviral therapy (HAART) naïve $(n=56)$ and on HAART with immune reconstitution inflammatory syndrome (IRIS) $(n=44)$. Among 56 individuals naive HAART, viral load $<1000 \mathrm{copies} / \mathrm{ml}$ was found in 44 individuals, among which 14 were female ( $34 \pm 1.953$ years) and 28 were male $(39.40 \pm 1.290$ years) whereas 12 individual had viral RNA $>1000$ copies $/ \mathrm{ml}$ among which 02 were female (34.83 \pm 2.030 years) and 10 were male $(41.34 \pm 1.462$ years). The comparison of CD4 count between the naïve and patients enrolled for HAART; the risk of having CD4 count $<200 \mathrm{cell} / \mathrm{mm}^{3}$ is significantly greater in male than that of female. The BMI ratio of HAART to naïve patients $(19.88 \pm 0.7290)$ was lower than that of HAART enrolled patients $(21.78 \pm$ $0.3546)$. The hemoglobin value showed significant $(P$ value $<0.0001)$ difference among PLHIV having CD4 level less than $200(9.9 \pm 2.156)$, between $200-500(11.63 \pm 1.946)$ and more than 500 CD4 level $(12.71 \pm 1.850)$. Significant $(\mathrm{P}<0.0001)$ viral load suppression showed among HAART initiated female patients with IRIS when compared with naïve female patients without IRIS. BMI, hemoglobin level, total leukocyte count, albumin level, HDL level, ESR value, CRP level and absolute eosinophil level less than 351 cells $/ \mathrm{mm}^{3}$ showed significant $(P<0.05)$ difference among HAART naïve and on HAART female patients with IRIS. Significant $(P<0.0001)$ viral load suppression showed among HAART initiated male patients with IRIS when compared with naïve female patients without IRIS. BMI (18-26), hemoglobin level below $8 \mathrm{~g} / \mathrm{dl}$, TLC, serum albumin level below $5 \mathrm{~g} / \mathrm{dl}$, HDL level below $61 \mathrm{mg} / \mathrm{dl}$, ESR level, CRP value and absolute eosinophil count showed significant $(P<0.05)$ difference between HAART naïve and on HAART male patients with IRIS. Hemoglobin level, HDL, TLC, ESR, CD8, AEC, viral load, BMI and serum albumin level showed significant $(P<0.0001)$ difference among HAART initiated patients with IRIS when compared to different level of CD4 T cell count.

Conclusion: Prevalence of anemia was high in HAART naïve patients while leucopenia prevalence was higher in patients on HAART and their prevalence increased as the CD4 count decreased. HIV Patients should be investigated for hematological and immunological changes following with appropriate therapeutic interventions. The study findings reemphasize the importance of nutritional and immunological parameters to assess the stage of the disease, initiate antiretroviral therapy and monitor the response in disease progression.

Keywords: Biomarkers; IRIS; HIV/AIDS

Abbreviations: HIV: Human Immunodeficiency Virus; AIDS: Acquired Immuno Deficiency Syndrome; ART: Anti-retroviral Therapy; CD4: Cluster of Differentiation 4; CD8+: Cluster Differentiation 8; FACS: Fluorescent Activated Cell Sorting; HAART: Highly Active Anti-Retroviral Therapy; HIV: Human Immunodeficiency Virus; IRIS: Immune Reconstitution Inflammatory Syndrome; OIs: Opportunistic Infections; PLHIV: People Living with HIV/AIDS (PLHIV); RNA: Ribonucleic Acid

\section{Introduction}

In 2015 there were 2.1 million (1.8 million-2.4 million) new HIV infections worldwide, adding up to a total of 36.7 million (34.0 million-39.8 million) people living with HIV (Global AIDS update, UNAIDS 2016). AIDS is a chronic disease that causes the progressive de- struction of the immune system, thus leading to recurring opportunistic infections, changes in body composition, adverse nutritional impact,

*Corresponding author: Dr. Krishna Das Manandhar, Central Department of Biotechnology, Tribhuvan University, Kritipur, Nepal; Tel: 9779841256246; E-mail: krishnamanandhar@gmail.com

Received August 06, 2017; Accepted September 12, 2017; Published September 19, 2017

Citation: Mishra SK, Khadka S, Dhital S, Mahto RK, Manandhar KD (2017) Biomarkers in Immune Reconstitution Inflammatory Syndrome (IRIS) among People Living with Human Immunodeficiency Virus/Acquired Immunodeficiency Syndrome (HIVIAIDS). J AIDS Clin Res 8: 728. doi: 10.4172/2155-6113.1000728

Copyright: () 2017 Mishra SK, et al. This is an open-access article distributed under the terms of the Creative Commons Attribution License, which permits unrestricted use, distribution, and reproduction in any medium, provided the original author and source are credited. 
Citation: Mishra SK, Khadka S, Dhital S, Mahto RK, Manandhar KD (2017) Biomarkers in Immune Reconstitution Inflammatory Syndrome (IRIS) among People Living with Human Immunodeficiency Virus/Acquired Immunodeficiency Syndrome (HIV/AIDS). J AIDS Clin Res 8: 728. doi: $10.4172 / 2155-6113.1000728$

evaluative debilitation and even death [1]. The correlation between the CD4 $\mathrm{T}$ cell count and viral load is fluctuating in presence or absence of HAART [2,3]. Incorporating immunological and biochemical markers into routine nutritional assessment provides an often-needed objective dimension [4].

Various authors have reported that the biological markers including nutritional state are a strong predictive factor for survival and functional conditions during the course of HIV infection [5-7]. The WHO classifies a $\mathrm{BMI}<18.5$ as a sign of malnutrition. However, BMI can be insensitive to changes in lean muscle mass (LMM), which is a more accurate marker of recent change in nutritional status. Anemia is a common hematological complication associated with HIV infection and has been implicated as a risk factor for mortality during HIV infection [8]. Approximately $20-80 \%$ of the people living with HIV/AIDS suffer from anemia which is directly associated with faster progression of disease [7]. Therefore, prevention of anemia may lead to improved health and survival potential of people living with HIV/AIDS [8]. As HIV/AIDS progresses, the severity and prevalence of anemia also increases [9]. However, leucopoenia in patients with HIV/AIDS more common [10]. Since HIV infects CD4+ lymphocytes, it can directly result in lymphopenia [11]. Serum albumin, which is not routinely measured in developing countries and is not available in most of the laboratory at ART center which is the most common laboratory parameter for nutritional assessment with low serum albumin indicating malnutrition $[5,6,9,10,12]$. Lipid profile abnormalities have been reported in the early stages of HIV infection and become more evident with the disease's progression $[13,14]$. There is large number of cytokines increase and serum triglyceride, HDL-cholesterol decrease during HIV infection [15]. It is already reported that Interferonalpha known to be elevated in HIV/AIDS individuals and is positively correlated with plasma triglyceride concentrations $[16,17]$.

An IRIS event was defined as either a first presentation or a paradoxical worsening of a pre-existing infection following initiation of HAART in the presence of a decreasing viral load and features consistent with an inflammatory process. In patients with a previous history of, for example, herpes simplex virus infection, recurrent disease was defined as an IRIS event only if there was documented evidence of a significant increased frequency, severity and/or poor treatment response in the 6 months after initiation of HAART. The objective of this study is to determine anthropometric measurements, immunological markers and nutritional indicators among HIV/AIDS Patients enrolled in HAART and HAART naive in HIV referral Centre of National public Health Laboratory, Nepal.

\section{Materials and Methods}

\section{Study population and definitions}

Patients $(\mathrm{n}=100)$ visiting National Public health laboratory, Teku, Kathmandu were enrolled in this study. A descriptive study with control group was carried out at National Public Health laboratory (NPHL), the apex laboratory of government of Nepal and Sukraraj Tropical Hospital Infectious Disease Hospital (STIDH) is the only Infectious \& Tropical Disease Hospital in Nepal and the biggest ART center. The criteria for the early prediction of people which may suffer IRIS were ratio of CD4/CD8 has been used for prediction of immune reconstitution inflammatory syndrome (IRIS) in future course of treatment. The development of IRIS in HIV-infected patients initiating antiretroviral therapy (ART) results from restored immunity to specific infectious or non-infectious antigens. A paradoxical clinical worsening of a known condition or the appearance of a new condition after initiating therapy characterizes the syndrome. Some researchers proposed the major criteria like atypical presentation of "opportunistic infections (OI) or tumors" in patients responding to antiretroviral therapy and decrease in plasma HIV RNA level by at least $1 \log 10$ copies/mL and as minor criteria like increased blood CD4+ T-cell count after highly active antiretroviral therapy (HAART), increase in immune response specific to the relevant pathogen and spontaneous resolution of disease without specific antimicrobial therapy or tumor chemotherapy with continuation of antiretroviral therapy.

HIV/AIDS patients were categorized into HAART naïve $(n=56$, $56 \%)$ and with IRIS enrolled $(\mathrm{n}=44,44 \%)$ patients. Among 56 naïve patients 34 were male and 22 were female whereas in HAART enrolled 44 (44\%), 28 were male and 16 were female. The followings were the inclusion criteria: age between 15 and 60 years and confirmed diagnosis of HIV. Patients who required intensive care during hospitalization were excluded. All patients were initiated on various HAART regimens by strictly following the national guideline. The common first-line regimens used were zidovudine (AZT) plus lamivudine (3TC) plus nevirapine (NVP); followed by stavudine (d4T) plus lamivudine (3TC) plus nevirapine (NVP); zidovudine plus 3TC plus efavirenz (EFV); and d4T plus 3TC plus EFV. The CD4 cell count, viral load, hemoglobin, albumin, high density lipid profile, total leukocyte count, erythrocyte sedimentation rate, presence/absence of C-reactive protein and absolute eosinophil count were performed using standard protocol. The following were the reference values for findings considered normal: HDLc $\geq 40$ to $<61 \mathrm{mg} / \mathrm{dl}, \mathrm{ESR} \geq 10$ to $<21 \mathrm{~mm} / \mathrm{h}$, albumin higher than $3.5 \mathrm{~g} / \mathrm{dl}$ in both sexes; hemoglobin equal to or higher than $12 \mathrm{~g} / \mathrm{dl}$ and for men; and hemoglobin equal to or higher than $12 \mathrm{~g} / \mathrm{dl}$ for women. For stratification of anemia, a hemoglobin concentration lower than $8 \mathrm{~g} / \mathrm{dl}$ was considered severely reduced, a hemoglobin concentration between 8 and $12 \mathrm{~g} / \mathrm{dl}$ was considered moderately reduced and a hemoglobin concentration equal to or higher than $12 \mathrm{~g} / \mathrm{dl}$ was considered normal. The CD4 cell count was interpreted based on the recommendations of the Ministry of Health and population, Government of Nepal which uses less than 350 cells $/ \mathrm{mm}^{3}$ as the cutoff point (lower than $350 \mathrm{cells} / \mathrm{mm}^{3}$ is one of the criteria used to define AIDS in patients with HIV, together with nutritional status and the presence of opportunistic diseases). Based on the BMI, the patients were classified as either underweight $\left(\mathrm{BMI}<18.5 \mathrm{~kg} / \mathrm{m}^{2}\right)$ or adequate weight $\left(\mathrm{BMI} \geq 18.5 \mathrm{~kg} / \mathrm{m}^{2}\right)$. Data collection, entry and validation, organization and monitoring approaches was used to generate data, double entry, auto correction and validation system was applied during data entry. A backup of every data was maintained. Moreover, results especially for lab experiments such as source data, errors observed and corrective action taken and comments on each activity was maintained. All the study data was entered into a computer database using standard format, checked for errors and verified. The variables were represented by pertinent descriptive statistics: absolute (n) and relative (\%) frequency or mean \pm SEM. Student's t-test for independent variables was used to compare means among groups of interest. The level of significance was set to $0.05(\alpha=5 \%)$. The statistical analysis was performed using SPSS 17.0 software.

\section{ELISA}

ELISA test for the detection of antibodies to HIV-1 and HIV2 in human plasma were used. The Bio ELISA HIV-1+2 (rec) (BIOKIT, Barcelona, Spain) is a third generation solid phase enzyme immunoassay in which highly purified recombinant antigens gp41, gp120 and gp36 are used for the combined detection of antibodies to HIV-1, HIV-2 and HIV-1 subtype O. The total number of wells needed for the assay was determined. In addition to test samples, 1 well for the 
Citation: Mishra SK, Khadka S, Dhital S, Mahto RK, Manandhar KD (2017) Biomarkers in Immune Reconstitution Inflammatory Syndrome (IRIS) among People Living with Human Immunodeficiency Virus/Acquired Immunodeficiency Syndrome (HIV/AIDS). J AIDS Clin Res 8: 728 . doi: $10.4172 / 2155-6113.1000728$

substrate blank, 3 wells for negative control, 2 wells for HIV-1 positive control and 1 well for HIV-2 positive control was allocated. The $100 \mu \mathrm{l}$ of sample diluent in each well except blank well, $50 \mu$ of each sample in the designated well, $50 \mu \mathrm{l}$ of negative control, $50 \mu \mathrm{l}$ of HIV-1 positive control and $50 \mu$ of HIV-2 positive control was dispensed. The plates along with the adhesive seals were incubated at $37^{\circ} \mathrm{C}$ for $60 \mathrm{~min} .100$ French 1 of detector antibody conjugates with horse reddish peroxidase (HRP) was added and incubated for $30 \mathrm{~min}$ at $37^{\circ} \mathrm{C}$. After that, $100 \mu \mathrm{L}$ trimethylbenzidine (TMB) substrate was added and incubated for 15 min at dark. The reaction was stopped by addition of $1 \mathrm{~N} \mathrm{H}_{2} \mathrm{SO}_{4}$ and $\mathrm{OD}$ was taken at $450 \mathrm{~nm}$ in ELISA plate reader (Bio-Rad). The cutoff value was determined by adding 0.120 to the mean absorbance of the negative control.

\section{RNA extraction and HIV viral load}

RNA was isolated from $140 \mu \mathrm{l}$ of serum sample using Nucleospin viral RNA isolation kit (MACHEREY-NAGEL, Germany) according to the manufacturer's instruction. For the viral RNA amplification and cDNA preparation Artus HI Virus-1 QS-RGQ Kit (QIAGEN, GmbH, Germany) was used and primers were supplied by manufacturer as complete master mix which was used to isolate HIV-1 genome fragment of $93 \mathrm{bp}$ which was later subjected for direct detection in fluorescence channel. Additionally, internal control was used as supplied in kit to identify possible PCR inhibition as detected by fluorescence channel orange in Rotor gene Q. External control was used to determine the amount of viral RNA.

\section{CD4+ T-lymphocytes assay}

Proportion of CD4+ T cells (Helper T cells) and CD8+ T cells (Inducer $\mathrm{T}$ cells) was calculated using immune-phenotyping by incubating anti-coagulated whole blood with monoclonal antibodies. The antibodies are conjugated to fluorescent tags that emit light of a certain frequency when excited by a laser beam. The specimens was analyzed on a flow cytometer Becton Dickinson (BD) FACS Count system (Becton, Dickinson and Company, California, USA) to determine the proportion of cells of a particular phenotype (that emit light at the right wavelength). The True Count method (Tri TEST 3-color) (Becton, Dickinson and Company, California, USA uses True Count tubes which contain a lyophilized pellet containing a known quantity of fluorescent beads. A precise quantity of whole blood was added to the tubes, and the lymphocytes are stained with Tri TEST monoclonal antibodies $(\mathrm{mAb})$ as instructed by manufacturer. The absolute count of a full lymphocyte subset profile $(\mathrm{CD} 3+, \mathrm{CD} 4+$ and CD45+) were determined in four tubes with Tri TEST and two tubes with Multi TEST by calculating the ratio of region events for each subset to bead events using the Multi SET (Becton, Dickinson and Company, California, USA).

\section{Results}

The patients were categorized into highly active antiretroviral therapy (HAART) naïve ( $\mathrm{n}=56)$ and on HAART with immune reconstitution inflammatory syndrome (IRIS) $(n=44)$. Among 56 individuals naive HAART, viral load $<1000$ copies/ml was found in 44 individuals, among which 14 were female ( $34 \pm 1.953$ years) and 28 were male $(39.40$ \pm 1.290 years) whereas 12 individual had viral RNA $>1000$ copies $/ \mathrm{ml}$ among which 02 were female $(34.83 \pm 2.030$ years $)$ and 10 were male ( $41.34 \pm 1.462$ years). The comparison of CD4 count between the naïve and patients enrolled for HAART; the risk of having CD4 count $<200$ cell $/ \mathrm{mm}^{3}$ is significantly greater in male than that of female. The BMI ratio of HAART to naïve patients $(19.88 \pm 0.7290)$ was lower than that of HAART enrolled patients $(21.78 \pm 0.3546)$. The hemoglobin value showed significant $(\mathrm{P}$ value $<0.0001)$ difference among PLHIV having CD4 level less than $200(9.9 \pm 2.156)$, between $200-500(11.63 \pm 1.946)$ and more than $500 \mathrm{CD} 4$ level $(12.71 \pm 1.850)$. The other hematological parameters estimated included were absolute eosinophil count (AEC) $(391.8 \pm 180.1)$, total leukocyte count (TLC) $(8595.8 \pm 2146.9)$ and erythrocyte sedimentation rate (ESR) $(75.625 \pm 29)$ Significant positive correlation was observed between CD4+T-cell counts and AEC, TLC and hemoglobin level. ESR and c reactive protein (CRP) was found to be negatively correlating with $\mathrm{CD} 4+\mathrm{T}$-cell counts.

Significant $(\mathrm{P}<0.0001)$ viral load suppression showed among HAART initiated female patients with IRIS when compared with naïve female patients without IRIS. BMI, hemoglobin level, total leukocyte count, albumin level, HDL level, ESR value, CRP level and absolute eosinophil level less than 351 cells $/ \mathrm{mm}^{3}$ showed significant $(\mathrm{P}<0.05)$ difference among HAART naive and on HAART female patients with IRIS as shown in Table 1.

\begin{tabular}{|c|c|c|c|c|}
\hline Parameters & Female & & Total & P Value \\
\hline & HIV Patients & & & \\
\hline & HAART naïve & On HAART & & \\
\hline \multicolumn{5}{|c|}{ Viral Load copies/ml } \\
\hline$<1000$ & 3 & 18 & 21 & $\mathrm{P}<0.0001$ \\
\hline$>1000$ & 16 & 1 & 17 & $P<0.0001$ \\
\hline \multicolumn{5}{|l|}{ CD4 } \\
\hline$<200$ & 1 & 3 & 4 & $P=0.1859$ \\
\hline$\geq 200-<500$ & 3 & 23 & 26 & $\mathrm{P}<0.0001$ \\
\hline$\geq \mathbf{5 0 0}$ & 2 & 7 & 9 & $\mathrm{P}=0.0220$ \\
\hline \multicolumn{5}{|l|}{ BMI } \\
\hline$<18$ & 2 & 6 & 8 & $P=0.0528$ \\
\hline$\geq 18-<26$ & 4 & 22 & 26 & $\mathrm{P}<0.0001$ \\
\hline$\geq 26$ & 0 & 3 & 3 & $\mathrm{P}=0.0253$ \\
\hline \multicolumn{5}{|l|}{$\mathrm{Hb}$ g/dl } \\
\hline$<8$ & 7 & 0 & 7 & $P=0.0253$ \\
\hline$\geq 8-<13$ & 1 & 8 & 9 & $P=0.0017$ \\
\hline$\geq 13$ & 5 & 19 & 24 & $P<0.0001$ \\
\hline \multicolumn{5}{|l|}{ TLC $\mathrm{mm}^{3} / \mathrm{ml}$} \\
\hline$<4000$ & 7 & 35 & 42 & $\mathrm{P}<0.0001$ \\
\hline $4000-11000$ & 0 & 0 & 0 & \\
\hline$>11000$ & 0 & 0 & 0 & \\
\hline \multicolumn{5}{|l|}{ Albumin } \\
\hline$<3.5$ & 2 & 13 & 15 & $P=0.0001$ \\
\hline$\geq 3.5-<5.0$ & 4 & 15 & 19 & $P=0.0004$ \\
\hline$\geq 5.0$ & 0 & 5 & 5 & $P=0.0253$ \\
\hline \multicolumn{5}{|l|}{ HDL mg/dl } \\
\hline$<40$ & 7 & 23 & 30 & $\mathrm{P}<0.0001$ \\
\hline$\geq 40-<61$ & 0 & 9 & 9 & $P=0.0253$ \\
\hline$\geq 61$ & 0 & 3 & 3 & $P=0.0253$ \\
\hline \multicolumn{5}{|l|}{ ESR $\mathrm{mm} / 1 \mathrm{~h}$} \\
\hline$<10$ & 0 & 2 & 2 & $\mathrm{P}=0.0253$ \\
\hline$\geq 10-<21$ & 1 & 5 & 6 & $\mathrm{P}=0.0286$ \\
\hline$\geq 21$ & 5 & 29 & 34 & $P<0.0001$ \\
\hline \multicolumn{5}{|l|}{ CRP } \\
\hline Positive & 1 & 12 & 13 & $P<0.0001$ \\
\hline Negative & 6 & 19 & 25 & $P=0.0003$ \\
\hline \multicolumn{5}{|c|}{ AEC cells $/ \mathrm{mm}^{3}$} \\
\hline$<50$ & 0 & 4 & 4 & $P=0.0253$ \\
\hline$\geq 50-<351$ & 6 & 29 & 35 & $\mathrm{P}<0.0001$ \\
\hline$\geq 351$ & 1 & 2 & 3 & $P=0.4606$ \\
\hline
\end{tabular}

Table 1: Clinical parameters in HAART naïve and HAART used female patients with IRIS. 
Citation: Mishra SK, Khadka S, Dhital S, Mahto RK, Manandhar KD (2017) Biomarkers in Immune Reconstitution Inflammatory Syndrome (IRIS) among People Living with Human Immunodeficiency Virus/Acquired Immunodeficiency Syndrome (HIV/AIDS). J AIDS Clin Res 8: 728 . doi: $10.4172 / 2155-6113.1000728$

Page 4 of 6

Significant $(\mathrm{P}<0.0001)$ viral load suppression showed among HAART initiated male patients with IRIS when compared with naïve female patients without IRIS. BMI (18-26), hemoglobin level below $8 \mathrm{~g} /$ $\mathrm{dl}$, TLC, serum albumin level below $5 \mathrm{~g} / \mathrm{dl}$, HDL level below $61 \mathrm{mg} / \mathrm{dl}$, ESR level, CRP value and absolute eosinophil count showed significant $(\mathrm{P}<0.05)$ difference between HAART naïve and on HAART male patients with IRIS as shown in Table 2.

Hemoglobin level, HDL, TLC, ESR, CD8, AEC, viral load, BMI and serum albumin level showed significant $(\mathrm{P}<0.0001)$ difference among HAART initiated patients with IRIS when compared to different level of CD4 T cell count as shown in Table 3.

\section{Demographics and epidemiological assessment}

Among $100 \mathrm{HIV} / \mathrm{AIDS}$ patients which were further categorized into HAART naïve $(\mathrm{n}=56,56 \%)$ and with IRIS enrolled $(\mathrm{n}=44,44 \%)$ patients. Among 56 naïve patients 34 were male and 22 were female whereas in

\begin{tabular}{|c|c|c|c|c|}
\hline Parameters & Male & & Total & $P$ value \\
\hline & HIV Patients & & & \\
\hline & HAART naïve & On HAART & & \\
\hline \multicolumn{5}{|c|}{ Viral Load copies/ml } \\
\hline$<1000$ & 8 & 35 & 43 & $P<0.0001$ \\
\hline$>1000$ & 17 & 2 & 19 & $P<0.0001$ \\
\hline \multicolumn{5}{|l|}{ CD4 } \\
\hline$<200$ & 3 & 13 & 16 & $P=0.0006$ \\
\hline$\geq 200$ to $<500$ & 6 & 23 & 29 & $P<0.0001$ \\
\hline$\geq 500$ & 5 & 11 & 16 & $P=0.0344$ \\
\hline \multicolumn{5}{|l|}{ BMI } \\
\hline$<18$ & 2 & 4 & 6 & $P=0.2595$ \\
\hline$\geq 18$ to $<26$ & 11 & 45 & 56 & $P<0.0001$ \\
\hline$\geq 26$ & 0 & 1 & 1 & $\mathrm{P}=0.0253$ \\
\hline \multicolumn{5}{|l|}{$\mathrm{Hb}$ g/dl } \\
\hline$<8$ & 10 & 0 & 10 & $\mathrm{P}=0.0253$ \\
\hline$\geq 8$ to $<13$ & 5 & 4 & 9 & $P=0.6801$ \\
\hline$\geq 13$ & 3 & 37 & 40 & $P<0.0001$ \\
\hline \multicolumn{5}{|l|}{ TLC mm³/ml } \\
\hline$<4000$ & 12 & 44 & 56 & $P<0.0001$ \\
\hline $4000-11000$ & 1 & 1 & 2 & $P=1.0000$ \\
\hline$>11000$ & 0 & 0 & 0 & \\
\hline \multicolumn{5}{|l|}{ Albumin } \\
\hline$<3.5$ & 6 & 19 & 25 & $P=0.0003$ \\
\hline$\geq 3.5$ to $<5.0$ & 7 & 21 & 28 & $P=0.0002$ \\
\hline$\geq 5.0$ & 1 & 4 & 5 & $P=0.0719$ \\
\hline \multicolumn{5}{|l|}{ HDL mg/dl } \\
\hline$<40$ & 17 & 21 & 38 & $P=0.3865$ \\
\hline$\geq 40$ to $<61$ & 1 & 15 & 16 & $P<0.0001$ \\
\hline$\geq 61$ & 0 & 4 & 4 & $P=0.0253$ \\
\hline \multicolumn{5}{|l|}{ ESR $\mathrm{mm} / 1 \mathrm{~h}$} \\
\hline$<10$ & 2 & 11 & 13 & $P<0.0001$ \\
\hline$\geq 10$ to $<21$ & 4 & 9 & 13 & $P=0.0574$ \\
\hline$\geq 21$ & 7 & 25 & 32 & $P<0.0001$ \\
\hline \multicolumn{5}{|l|}{ CRP } \\
\hline Positive & 3 & 14 & 17 & $P<0.0001$ \\
\hline Negative & 10 & 35 & 45 & $P<0.0001$ \\
\hline \multicolumn{5}{|l|}{ AEC cells $/ \mathrm{mm}^{3}$} \\
\hline$<50$ & 2 & 10 & 12 & $P<0.0001$ \\
\hline$\geq 50$ to $<351$ & 6 & 34 & 40 & $P<0.0001$ \\
\hline$\geq 351$ & 5 & 1 & 6 & $P<0.0001$ \\
\hline
\end{tabular}

Table 2: Clinical parameters in HAART naïve and HAART used male patients with IRIS.

\begin{tabular}{|l|c|c|c|c|}
\hline Parameters & & \multicolumn{2}{|c|}{ CD4 Count } & P value \\
\hline $\mathrm{Hb}$ & $<200$ & $\geq 200$ to $<500$ & $\geq 500$ & \\
\hline $\mathrm{HDL}$ & $9.9 \pm 2.156$ & $11.63 \pm 1.946$ & $12.71 \pm 1.850$ & $<0.0001$ \\
\hline TLC & $27.25 \pm 9.142$ & $40.93 \pm 19.08$ & $34.59 \pm 15.33$ & 0.003 \\
\hline ESR & $57.28 \pm 1.383$ & $172.28 \pm 1.42$ & $717.1 \pm 3.38$ & $<0.0001$ \\
\hline CD8 & $23.11 \pm 3.12$ & $34.42 \pm 2.12$ & $43.23 \pm 4.22$ & $<0.0001$ \\
\hline AEC & $232 \pm 1.23$ & $348 \pm 2.12$ & $573 \pm 1.11$ & $<0.0001$ \\
\hline Viral Copy No. & $4910 \pm 1.31$ & $1223 \pm 1.11$ & $400 \pm 1.12$ & $<0.0001$ \\
\hline BMl & $15.2 \pm 1.12$ & $12.12 \pm 1.12$ & $17.13 \pm 1.42$ & $<0.0001$ \\
\hline Albumin & $3.12 \pm 1.2$ & $4.121 \pm 1.22$ & $5.131 \pm 1.12$ & $<0.0001$ \\
\hline
\end{tabular}

*values in mean \pm SEM

Table 3: Co-relation between CD4 level and clinical parameters among HAART patients with IRIS

HAART enrolled 44 (44 \%), 28 were male and 16 were female. The BMI ratio of HAART naïve patients $(19.88 \pm 0.7290)$ was lower than that of HAART enrolled patients $(21.78 \pm 0.3546)$. However, HAART naïve patients $(35.60 \pm 1.746)$ were younger compared to HAART enrolled patients $(38.02 \pm 0.8827)$. Female naïve patients $(34.33 \pm 3.703)$ were comparatively younger compared to male naïve patients $(36.14 \pm 2.008)$ same as HAART enrolled patients [female $(34.45 \pm 1.362)$ and male $(40.53 \pm 1.020)]$ (Table 4$)$.

\section{CD4 counts and viral load}

The population was divided into 3 groups according to the CD4 counts: CD $4 \geq 500 \mathrm{cell} / \mathrm{mm}^{3}$ (stage 1 ), $\mathrm{CD} \geq 200-<500 \mathrm{cell} / \mathrm{mm}^{3}$ (stage 2), $\mathrm{CD}<200 \mathrm{cell} / \mathrm{mm}^{3}$ (stage 3 ). Compared between naïve and HAART enrolled patients the probability of CD4 count, the risk of having CD4 count $<200 \mathrm{cell} / \mathrm{mm}^{3}$ is significantly greater in male than that of female in naïve to HAART enrolled patients. Also, the chances of having CD4 counts between $\geq 200$ to $<500$ is greater than 3 times in naive compared to HAART enrolled males, however its greater than 7 times in naive versus HAART enrolled female \%). Among individuals naive HAART, viral load $<1000$ copies $/ \mathrm{ml}$ was found in 49 individuals, among which 14 were female $(34 \pm 1.953$ years $)$ and 28 were male $(39.40 \pm 1.290$ years) whereas 51 individual had viral RNA $>1000$ copies $/ \mathrm{ml}$ among which 22 were female $(34.83 \pm 2.030$ years $)$ and 29 were male $(41.34 \pm$ 1.462 years). The CD4 count and clinical parameters for diagnosis was not significant besides BMI, Hb, TLC, ESR, CD8, AEC and Albumin. The tendency of increment above critical value was observed in above mentioned parameters whenever CD4 count was increasing (Table 3).

\section{Clinical parameters for disease progression}

The hemoglobin value showed significant $(P$ value $<0.0001)$ difference among PLHIV having CD4 level less than 200 (9.9 \pm 2.156$)$, between 200-500 $(11.63 \pm 1.946)$ and more than 500 CD4 level (12.71 \pm 1.850 ). There was no case for macrocytic and normocytic but a single case of microcytic among total patients. High density lipoprotein $<40$ $\mathrm{mg} / \mathrm{dl}$ was observed in significant $(\mathrm{P}$ value $<0.0001)$ population in male $(n=21)$ and female $(n=23)$. HAART with IRIS enrolled patients compared to their naive counterparts. Total leukocyte count was less than 4000 cells $/ \mathrm{mm}^{3}$ in $98 \%$ of patients among which 56 were male and 42 were female while $2 \%$ patients had total leukocyte count of more than 4000 cells $/ \mathrm{mm}^{3}$.

\section{Discussion}

The prevalence of anemia in patients with AIDS is estimated to be between 63 and $95 \%[18,19]$. Thus, the rate of $35 \%$ in the present study is in agreement with findings reported in the literature. There is possibility of multiple cause of anemia in the people living with 
Citation: Mishra SK, Khadka S, Dhital S, Mahto RK, Manandhar KD (2017) Biomarkers in Immune Reconstitution Inflammatory Syndrome (IRIS) among People Living with Human Immunodeficiency Virus/Acquired Immunodeficiency Syndrome (HIV/AIDS). J AIDS Clin Res 8: 728 . doi: $10.4172 / 2155-6113.1000728$

Page 5 of 6

\begin{tabular}{|c|c|c|c|c|}
\hline Parameters & Male & & Female & \\
\hline & $\begin{array}{l}\text { HIV } \\
\text { Patients }\end{array}$ & & $\begin{array}{c}\text { HIV } \\
\text { Patients }\end{array}$ & \\
\hline & $\begin{array}{l}\text { HAART } \\
\text { naïve }\end{array}$ & $\begin{array}{c}\text { On } \\
\text { HAART }\end{array}$ & $\begin{array}{c}\text { HAART } \\
\text { naïve }\end{array}$ & $\begin{array}{c}\text { On } \\
\text { HAART }\end{array}$ \\
\hline \multicolumn{5}{|l|}{ Age } \\
\hline$<25$ & 0 & 0 & 0 & 2 \\
\hline$\geq 25$ to $<50$ & 13 & 41 & 6 & 35 \\
\hline$\geq 51$ & 1 & 3 & 0 & 0 \\
\hline \multicolumn{5}{|l|}{ Viral Load copies/ml } \\
\hline$<1000$ & 8 & 35 & 3 & 18 \\
\hline$>1000$ & 17 & 2 & 16 & 1 \\
\hline \multicolumn{5}{|l|}{ CD4 } \\
\hline$<200$ & 3 & 13 & 1 & 3 \\
\hline$\geq 200$ to $<500$ & 6 & 23 & 3 & 23 \\
\hline$\geq \mathbf{5 0 0}$ & 5 & 11 & 2 & 7 \\
\hline \multicolumn{5}{|l|}{ BMI } \\
\hline$<18$ & 2 & 4 & 2 & 6 \\
\hline$\geq 18$ to $<26$ & 11 & 45 & 4 & 22 \\
\hline$\geq 26$ & 0 & 1 & 0 & 3 \\
\hline \multicolumn{5}{|l|}{$\mathrm{Hb}$ g/dl } \\
\hline$<8$ & 10 & 0 & 7 & 0 \\
\hline$\geq 8$ to $<13$ & 5 & 4 & 1 & 8 \\
\hline$\geq 13$ & 3 & 37 & 5 & 19 \\
\hline \multicolumn{5}{|l|}{ TLC mm³/ml } \\
\hline$<4000$ & 12 & 44 & 7 & 35 \\
\hline $4000-11000$ & 1 & 1 & 0 & 0 \\
\hline$>11000$ & 0 & 0 & 0 & 0 \\
\hline \multicolumn{5}{|l|}{ Albumin } \\
\hline$<3.5$ & 6 & 19 & 2 & 13 \\
\hline$\geq 3.5$ to $<5.0$ & 7 & 21 & 4 & 15 \\
\hline$\geq 5.0$ & 1 & 4 & 0 & 5 \\
\hline \multicolumn{5}{|l|}{ HDL mg/dl } \\
\hline$<40$ & 17 & 21 & 7 & 23 \\
\hline$\geq 40$ to $<61$ & 1 & 15 & 0 & 9 \\
\hline$\geq 61$ & 0 & 4 & 0 & 3 \\
\hline \multicolumn{5}{|l|}{ ESR mm/1 h } \\
\hline$<10$ & 2 & 11 & 0 & 2 \\
\hline$\geq 10$ to $<21$ & 4 & 9 & 1 & 5 \\
\hline$\geq 21$ & 7 & 25 & 5 & 29 \\
\hline \multicolumn{5}{|l|}{ CRP } \\
\hline +ve & 3 & 14 & 1 & 12 \\
\hline -ve & 10 & 35 & 6 & 19 \\
\hline \multicolumn{5}{|l|}{ AEC cells $/ \mathrm{mm}^{3}$} \\
\hline$<50$ & 2 & 10 & 0 & 4 \\
\hline$\geq 50$ to $<351$ & 6 & 34 & 6 & 29 \\
\hline$\geq 351$ & 5 & 1 & 1 & 2 \\
\hline \multicolumn{5}{|l|}{ ART Regimes } \\
\hline $\begin{array}{lc}\text { Nucleoside } & \text { Reverse } \\
\text { Transcriptase Inhibitor }\end{array}$ & 0 & 39 & 0 & 30 \\
\hline $\begin{array}{l}\text { Non-Nucleoside Reverse } \\
\text { Transcriptase Inhibitor }\end{array}$ & 0 & 39 & 0 & 30 \\
\hline HIV Protease Inhibitors & 0 & 39 & 0 & 30 \\
\hline HIV Fusion Inhibitors & 0 & 0 & 0 & 0 \\
\hline
\end{tabular}

1. Nucleoside Reverse Transcriptase Inhibitor: Zidovudine (AZT), Didanosine (DDI), Zalcitabine (DDC), Emtricitabine (FTC), Lamivudine (3TC), Tenofovir (TDF), Stavudine (d4T), Abacavir (ABC)

2.Non-Nucleoside Reverse Transcriptase Inhibitor: Nevirapine (NVP),

Delaviridine (DLV), Efavirenz (EFV)

3. HIV Protease Inhibitors: Tipranavi (TPV), Amprenavir (APV), Indinavir (IDV), Saquinavir (SQV), Ritonavir (RTV), Atazanavir (ATV), Fosamprenavir (FPV), Nelfinavir (NFV)

Table 4: Clinical parameters in HAART naïve patients and HAART used patients with IRIS.

HIV/AIDS, majority of them have major bone marrow dysfunction and co-infected with other microorganism including virus [20-22]. The other cause of reduction in hemoglobin concentration is the shortage of micronutrients like deficiency of iron, vitamin B12 and B9 required for haematopoiesis [19]. Although, patients with HIV/AIDS are nutritionally compromised and have anemia, it does not seem to depend on the recent intake of iron [23]. This study shows there is an association of low albumin levels among HIV patients [14]. There is positive correlation of serum albumin level of with CD4 count (Table 1). Another, study showed that the acute phase has crucial function for the host's reaction to infection [24]. It has been reported that HIV-infection promotes an enhancement of the fractional and absolute synthesis rates of positive acute-phase proteins, including haptoglobin [25]. Previously reported data on acute-phase proteins in HIV infection are conflicting. Many report on higher plasma concentrations of $\mathrm{C}$ reactive protein in a group of HIV/AIDS patients compared to the plasma concentrations of healthy controls [26] which is also shown in this study. Hypertriglyceridemia has been reported as the first lipid alteration in HIV infection and we also found decrement in HDL-cholesterol as reported in the HIV-infection. HDL-cholesterol has been considered as a marker of disease progression however HDL-cholesterol was lower in the patient on ART than naive patient, indicating a risk of heart disease $[27,28]$. Hematological parameters are often crucial for disease progression monitoring [11] but due to gold standard HAART and its predefined criteria for CD4 count, these clinical parameters often go undiagnosed. Even in resource limited setting like Nepal, where the CD4 counting infrastructure is limited, these parameters become crucial for diagnosis of disease progression. Despite of the immense utility of these biomarkers, the definitive pattern are not clear. In our study, we find out significant correlation between increments on the relative value defining normal range of $\mathrm{BMI}, \mathrm{Hb}$, TLC, ESR, CD8, AEC and Albumin which were on increment along with CD4 counts which was confirmed by another studies as well $[10,4,12]$. Our work also shed light on the age difference of male and female acquiring infection and provided evidence that in fact female are more prone to HIV infection than male at younger age. The HAART enrolled patients had significantly lower viral copy number in their serum compared to that of naïve but was not consistent with the relapsed number of CD4 count which may provide the case of immunological failure [13]. This study elicits the need of more study related to immunological parameters thus providing precise diagnosis and surveillance of HIV patients.

The correlation between parameters like HDL and viral load was not significant in some HAART enrolled cases, which points out the limitation of the study regarding sample size, maybe better sampling and enlarged cohort may sort out this problem. The work regarding clinical parameters which could be fruitful for developing nation like Nepal, limits crucially regarding routine CD4 and viral load, thus baselines for routine diagnostic taking immunological and physiological parameters are today's need.

\section{Conclusion}

Anemia, leucopoenia, hypoalbuminia and lipid disorders were common clinical events among the people living with HIV/AIDS Prevalence of anemia was high in HAART naïve patients while leucopoenia prevalence was higher in patients on HAART with IRIS. Anemia and leucopoenia was found to be directly associated with decrease CD4 count.

Prevalence of anemia was high in HAART naïve patients while leucopenia prevalence was higher in patients on HAART and their prevalence increased as the CD4 count decreased. HIV Patients should be 
Citation: Mishra SK, Khadka S, Dhital S, Mahto RK, Manandhar KD (2017) Biomarkers in Immune Reconstitution Inflammatory Syndrome (IRIS) among People Living with Human Immunodeficiency Virus/Acquired Immunodeficiency Syndrome (HIV/AIDS). J AIDS Clin Res 8: 728 . doi: $10.4172 / 2155-6113.1000728$

Page 6 of 6

investigated for hematological and immunological changes following with appropriate therapeutic interventions. The study findings reemphasize the importance of nutritional and immunological parameters to assess the stage of the disease, initiate antiretroviral therapy and monitor the response in disease progression. After completion of this study, we suggest the people living with HIV/AIDs should check their CD4 counts regularly and to start HAART when it is appropriate in order to decrease the prevalence of anemia. The CD4+ counts, HIV viral load, nutritional and immunological parameter should be checked in regular basis which help the people to monitor the outcome of disease.

\section{Authors' Contributions}

SKM, KDM and RKM were responsible for study design, supervision of work and guidance. SKM, SK and SD were contributed to laboratory work and data analysis. SKM, SK and SD were contributed to writing and manuscript preparation.

All authors read and approved the final manuscript.

\section{Acknowledgement}

I would like to acknowledge the all staffs National Public Health Laboratory, HIV Reference Unit, Nepal.

\section{References}

1. Duncombe C, Rosenblum S, Hellmann N, Holmes C, Wilkinson L, et al. (2015) Reframing HIV care: Putting people at the centre of antiretroviral delivery. Trop Med Int Health 20: 430-447.

2. Cortes FH, Passaes CP, Bello G, Teixeira SL, Vorsatz C, et al. (2015) HIV controllers with different viral load cut-off levels have distinct virologic and immunologic profiles. J Acquir Immune Defic Syndr 68: 377-385.

3. Chirouze C, Journot V, Le Moing V, Raffi F, Piroth L, et al. (2015) Viremia copyyears as a predictive marker of all-cause mortality in HIV-1-infected patients initiating a protease inhibitor containing antiretroviral treatment. J Acquir Immune Defic Syndr 68: 204-208.

4. Owiredu WK, Quaye L, Amidu N, Addai-Mensah O (2011) Prevalence of anaemia and immunological markers among ghanaian HAART-naive HIVpatients and those on HAART. Afr Health Sci 11: 2-15.

5. Santos AC, Almeida AM (2013) Nutritional status and CD4 cell counts in patients with HIVIAIDS receiving antiretroviral therapy. Rev Soc Bras Med Trop 46: 698-703.

6. Sudfeld CR, Isanaka S, Aboud S, Mugusi FM, Wang M, et al. (2013) Association of serum albumin concentration with mortality, morbidity, CD4 T-cell reconstitution among Tanzanians initiating antiretroviral therapy. J Infect Dis 207: $1370-1378$.

7. Tang AM, Bhatnagar T, Ramachandran R, Dong K, Skinner S, et al. (2011) Malnutrition in a population of HIV-positive and HIV-negative drug users living in Chennai, South India. Drug Alcohol Depend 118: 73-77.

8. Anyabolu HC, Adejuyigbe EA, Adeodu OO (2014) Undernutrition and anaemia among HAART-naive HIV infected children in lle-lfe, Nigeria: A case-controlled, hospital based study. Pan Afr Med J 18: 77.

9. Hadigan C, Edwards E, Rosenberg A, Purdy JB, Fleischman E, et al. (2013) Microalbuminuria in HIV disease. Am J Nephrol 37: 443-451.

10. Chauhan NK, Vajpayee M, Singh A (2011) Usefulness of hemoglobin and albumin as prognostic markers for highly active antiretroviral therapy for HIV-1 infection. Indian J Med Sci 65: 286-296.
11. Adewuyi JO, Coutts AM, Latif AS, Smith H, Abayomi AE, et al. (1999) Haematologic features of the human immunodeficiency virus (HIV) infection in adult Zimbabweans. Cent Afr J Med 45: 26-30.

12. Ramana KV, Sabitha V, Rao R (2013) A study of alternate biomarkers in HIV disease and evaluating their efficacy in predicting T CD4+ cell counts and disease progression in resource poor settings in highly active antiretroviral therapy (HAART) era. J Clin Diagn Res 7: 1332-1335.

13. Ferreyra C, Yun O, Eisenberg N, Alonso E, Khamadi AS, et al. (2012) Evaluation of clinical and immunological markers for predicting virological failure in a HIVI AIDS treatment cohort in Busia, Kenya. PLoS ONE 7: e49834.

14. Belperio PS, Rhew DC (2004) Prevalence and outcomes of anemia in individuals with human immunodeficiency virus: A systematic review of the literature. Am J Med 116: 27S-43S.

15. Doukas MA (1992) Human immunodeficiency virus associated anemia. Med Clin North Am 76: 699-709.

16. Volberding $P$ (2002) The impact of anemia on quality of life in human immunodeficiency virus-infected patients. J Infect Dis 185: S110-S114.

17. Dikshit B, Wanchu A, Sachdeva RK, Sharma A, Das R (2009) Profile of hematological abnormalities of Indian HIV infected individuals. BMC Blood Disord 9: 5.

18. Mocroft A, Kirk O, Barton SE, Dietrich M, Proenca R, et al. (1999) Anaemia is an independent predictive marker for clinical prognosis in HIV-infected patients from across Europe. AIDS 13: 943-950.

19. Sogaard OS, Reekie J, Ristola M, Jevtovic D, Karpov I, et al. (2013) Severe bacterial non-aids infections in HIV-positive persons: incidence rates and risk factors. J Infect 66: 439-446.

20. Rosenfeld SJ, Young NS (1991) Viruses and bone marrow failure. Blood Rev 5: 71-77.

21. Wang L, Mondal D, La Russa VF, Agrawal KC (2002) Suppression of clonogenic potential of human bone marrow mesenchymal stem cells by HIV type 1: Putative role of HIV type 1 tat protein and inflammatory cytokines. AIDS Res Hum Retroviruses 18: 917-931.

22. Donahue RE, Johnson MM, Zon LI, Clark SC, Groopman JE (1987) Suppression of in vitro haematopoiesis following human immunodeficiency virus infection. Nature 326: 200-203.

23. Monteiro JP, Cunha DF, da Cunha SF, dos Santos VM, Silva-Vergara ML, et al. (2000) Iron status, malnutrition and acute phase response in HIV-positive patients. Rev Soc Bras Med Trop 33: 17580.

24. Feingold KR, Grunfeld C (1992) Role of cytokines in inducing hyperlipidemia Diabetes 41: 97-101.

25. Grunfeld C, Feingold KR (1992) The role of the cytokines, interferon alpha and tumor necrosis factor in the hypertriglyceridemia and wasting of AIDs. J Nutr 122: 749-753.

26. Grunfeld C, Kotler DP, Shigenaga JK, Doerrler W, Tierney A, et al. (1991) Circulating interferon-alpha levels and hypertriglyceridemia in the acquired immunodeficiency syndrome. Am J Med 90: 154-162.

27. Caramelli B, de Bernoche CY, Sartori AM, Sposito AC, Santos RD, et al. (2001) Hyperlipidemia related to the use of HIV-protease inhibitors: Natural history and results of treatment with fenofibrate. Braz J Infect Dis 5: 332-338.

28. Daniyam C, Iroezindu M (2013) Lipid profile of anti-retroviral treatment-naive HIV-infected patients in Jos, Nigeria. Ann Med Health Sci Res 3: 26-30. 